\title{
Yigal Bloch. "The Contribution of Babylonian Tablets in the Collection of David Sofer to the Chronology of the Revolts against Darius I"
}

\section{Astrid Nunn}

\author{
(2) OpenEdition \\ Journals \\ Édition électronique \\ URL : http://journals.openedition.org/abstractairanica/45489 \\ DOI : 10.4000/abstractairanica.45489 \\ ISBN : 1961-960X \\ ISSN : 1961-960X \\ Éditeur : \\ CNRS (UMR 7528 Mondes iraniens et indiens), Éditions de l'IFRI
}

\section{Référence électronique}

Astrid Nunn, « Yigal Bloch. "The Contribution of Babylonian Tablets in the Collection of David Sofer to the Chronology of the Revolts against Darius I" », Abstracta Iranica [En ligne], Volume 37-38-39 | 2018, document 45, mis en ligne le 30 décembre 2018, consulté le 27 septembre 2020. URL : http:// journals.openedition.org/abstractairanica/45489; DOI : https://doi.org/10.4000/abstractairanica. 45489

Ce document a été généré automatiquement le 27 septembre 2020.

Tous droits réservés 


\title{
Yigal Bloch. "The Contribution of Babylonian Tablets in the Collection of David Sofer to the Chronology of the Revolts against Darius I"
}

\author{
Astrid Nunn
}

\section{RÉFÉRENCE}

Yigal Bloch. "The Contribution of Babylonian Tablets in the Collection of David Sofer to the Chronology of the Revolts against Darius I", AoF 42/1, 2015, p. 1-14.

1 Cette contribution traite de deux rébellions qui eurent lieu au début de l'histoire de l'Empire achéménide entre 522 et 520 av. J.-C. En combinant les sources classiques que sont Bisutun et les tablettes babyloniennes avec les tablettes de la collection privée de David Sofer nouvellement mises à la disposition de tous, l'A. élabore un agenda précis pour la rébellion de AraHa contre Nabuchodonosor IV en Babylonie (521 av. J.-C.). Le second problème est de savoir si Bardiya II fut reconnu ou non en Babylonie. Il semble qu'il ne le fut pas.

\section{AUTEURS}

ASTRID NUNN

Université de Munich 